\title{
THE IMPACT OF COMPUTER ASSISTED LANGUAGE LEARNING (CALL) USE OF ENGLISH VOCABULARY ENHANCEMENT
}

\author{
Yuri Lolita ${ }^{1}$ \\ Universitas Negeri Jakarta, Indonesia, \\ Endry Boeriswati ${ }^{2}$ \\ Universitas Negeri Jakarta, Indonesia, \\ Ninuk Lustyantie ${ }^{3}$ \\ Universitas Negeri Jakarta, Indonesia, \\ yurilolita_7317110596@mhs.unj.ac.id ${ }^{1}$ \\ Submit, 22-12-2019 Accepted, 30-12-2020 Publish, 30-12-2020
}

\begin{abstract}
This study aims at improving students' comprehension on English vocabulary using computer and finding out the effectiveness, efficiency and the attractiveness of Computer Assisted Language Learning (CALL) in English learning. It was carried out at SMP Sunan Giri Gresik by using proactive action research method and intervention action model. The participants belonged to 3 different class groups. Thirty of them were from 7th grade (Amanah class) and thirty-two of them from (Hidayah class). The other 30 participants from (Inayah class). The data were collected and analyzed by using mixed method approach. Instruments used for collecting data in this study are questionnaires, documents, observation check list, interview, and achievement tests. The results showed that the treatments give affect positively for students especially treatment on cycle 2 . It also can be seen by the students' involvement actively during learning process. Computer assisted learning especially using software gave students chance to explore their English skill especially the vocabulary through interacting directly with computer by doing exercises given individually in pair or group. From the explanation above it can be concluded that English learning in junior high school can be improved with the help of computer assistance in this matter called Computer-Assisted Language Learning (CALL) mainly to improve English vocabulary.
\end{abstract}

Keywords: Computer-assisted language learning (CALL), English vocabulary, Students' comprehension 


\section{INTRODUCTION}

As part of research and development agenda, we are currently focusing on the impact of information and Communication Technology (ICT) on teaching and learning English (Hashemi, 2016). It in junior high school especially vocabulary learning still far from expectation. The learning has been done till nowadays emphasizes on four language skills those are reading, speaking, listening and writing which also never been achieved, aside from that the learning is still focus on teacher or teacher-centered where teachers are very active in class resulting, the students to be passive and receiving anything given by the teachers. The students only come in class sit down and listen to all direction order and anything given by the teacher because they believed that it is the only way they can be perceived as good and obedient students. Whereas, as teacher, one's function and task are to teach the students so the language learning goal can be achieved instead of focusing only to the grammar teaching (Lomax \& Ferguson, 2002). Vocabulary knowledge is often viewed as a critical tool for second language learners because a limited vocabulary in a second language impedes successful communication. So that, Underscoring the importance of vocabulary acquisition (Alqahtani, 2015).

Vocabulary is often found; many students are not being able to speak and understand the text and write in English caused by lack of vocabulary which made them are not capable to choose or speak the words. This caused the students to have difficulty in listening properly what native speakers said or people who speak English or even the teacher who deliver information, direction or lesson in school. From some research it is known that one of factors which lead to low English score and students' failure to use this language especially in communicative way is their lack of vocabulary. This condition caused students to feel scared or not confident to state opinion feeling, suggestions, or question so most of them choose to be silent rather than expressing their opinion in English learning in class.

Due to that condition and circumstances the target and function of English learning cannot be used as it supposed to be where mastering this language will escort them to the success. Same opinion stated Gilakjani, (2017) that language in general has central role in social intellectual development and human emotional. Therefore, Ahmadi (2018) stated that students as learning subjects in school should understand that language learning can become beneficial in succession learning study field because language is tool to think scientifically.

Globalization that is supported by function of communication and information technology requires communicative society. Therefore, the English comprehension and technology devices such as computer and internet are requirement for society development (Md Ruhul, 2019). As the controller in the 
learning process it is better for teacher to do self-reflection and find more potential to find proper approach in teaching English especially vocabulary to students one of it by using technology to help learning process in class. Study found that one of the factors causing students lack of vocabulary is the ineffective and unvaried teaching techniques using by teachers in learning process especially in vocabulary learning. As we know that the success of teaching is determined on how teachers delivering the learning material to the students. Thus, teachers need to find, develop and make effective technique to motivate students in learning and improving their vocabulary comprehension one of it by using CALL (ComputerAssisted Language Learning) an alternative method to assist classical methods that commonly used in class.

In teaching the students according to Amin (2013) teachers need to master the use of ICT for the learning necessity. According to Ghavifekr, \& Rosdy, (2015) expressed that effective teacher require to create learning environment which supporting the learning process that is using technology in learning, enable to develop the technology skill and integrate it with computers in learning process in class which is adjusted by the students' necessity. The use computers in learning are not new thing but media has not even used whole of it in learning to ease and to provide facility for the students in learning. The writer has teaching experience during class with the results of observations of friends and colleagues, it seems that the use of computer-based media has not been used in the learning process. In this sophisticated era, it is very suitable when learning process to use computers as a learning media. If we see from demands and expectation from society, the English learning is supposed to use interesting approach which can motivate students so it can improve their English teacher, the language can be used to communication spoken and written. Nevertheless based on many studies done by many parties also observation result and early study, it is seen that English learning process that has been ongoing most of them focus on knowledge dimension and grammar comprehension with limited approach such as lecturing, doing answer sheet to student which most of them lie on grammar and in general the learning is done by teacher without using any media.

In order to solve the problems in conducting the English learning process and to improve the success of learning and English vocabulary comprehension in order to face the challenges and expectation from society that to use English in communicative way so that it needs strategic solutions that will solve the problem. Thus, the learning quality can be improved and suitable of education development and society and environment demands can be done by using educational technology (Darling-Hammond, et.al, 2020).

This research is intended to know and improve the English learning through computer especially English vocabulary comprehension improvement 
effectively, efficient and learning process which has attraction. Based on the problem, the purposed to (1) improve English vocabulary through computer assisted learning (2) improving the effectively of English learning by using computer (3) improving efficiency of computer assisted English learning can improve effectively English learning (4) make English learning to be more attractive.

In the learaning process teachers are expected to teach effectively, to guide students and to keep order in the classroom. However, the most crucial role teachers are expected to play is providing and maintaining a good quality of education. (Koran, 2015; Leu, 2005).

English is one of the skills determining by field workers and even though it is still seeing as second language as in Malaysia and India, English has already must lesson in junior high school. Therefore, the English learning can be successful according to Gagne \& M, (1984) there are nine points that is need to consider: (1) gaining Attention; student effort to gain teacher attention, (2) informing learner of the objectives; tell the students about the goal of the learning, (3) stimulating recall of prior learning; this called apperception to give students simultaneity so they can link prior material with new one, (4) presenting stimulus; provide the stimulus, (5) providing learning guidance; give guidance to students, (6) eliciting performance; improve performance, (7) providing feedback; giving feedback, (8) assessing performance; measure and assess students outcome and achievement in learning (9) enhancing retention and transfer; enhance the purpose as expected. For language to be mastered by the kids that the important thing they should know is proper vocabulary aside from grammatical skill because language includes every aspect in human's life (Alqahtani, 2015). That language implicitly and explicitly defines human life wherever he is in because language includes all the human aspects that is experienced by them also create and describe their experiences. It is impossible that human can live without language.

Vocabulary learning is big task and continuous for that teacher need to be involved by giving input and support to the students. As stated by Nation, (1974) that teacher should help students by: (1) introduce them to many terms; (2) learn students with various methods so they get used to it. (3) Give chances to students to choose what they want to learn and choose how to learn it. (4) Motivate them and give them chance to reflect and evaluate the learning outcome. According to Nation by Nunan, et.al, 2003), there are four vocabulary learning: (1) Learning from meaning-focus to input - learning by listening and reading, (2) Learn the language purposely focus on learn-learn that is taught through voice, vocabulary, grammar and conversation, (3) Learning from meaning focus to output learning through producing language by speaking and writing, (4) improving the fluency by speed in and certain in listening speaking reading and writing one of the factors 
that causing education quality in Indonesia low is that learning motivation for students is low when learning proses teacher do not apply interactive learning. Interactive learning can be applied by teacher through learning media function. According to Kemp and Dayton on Smaldino (2007) is (1) the standard of learning message delivered, (2) the learning become more interesting, (3) the learning become more interactive by applying learning theory, (4) the learning period can be shortening, (5) learning process can be improved, (6) the learning process can be done whenever and wherever they want, (7) positive attitude from student to learning process can be enhanced, (8) teacher role change positively. Computer has double role in learning start from curriculum till students learning media. Teacher can use computer as tool to collect information about student's outcome and arrange activities in class either using computers in class or many computers that support the learning process.

\section{LITERATURE REVIEW}

Language learning strategies required specific actions, behavior and techniques to improve student apprehending, internalizing and using the target language. Based on the research of Hadi et al, it concluded that the different language setting tends to lead the different use of language learning strategies (Hadi, Raja, \& Flora, 2017).

Recent research indicates that teaching vocabulary may be problematic because many teachers are not confident about the best practice in vocabulary teaching and at times do not know where to begin to form an instructional emphasis on word learning (Wahid, et.al, 2009).

Student-centered methods and strategies ought to be applied from early ages because children are curious by nature and self-reliant in discovering their surroundings. Students-centered teaching, in fact, meets young learners' genius which help students and teachers in the teaching-learning process (Shabaneh \& Farrah, 2019).

According to Dick, et.al, (2005), learning is series of activities that is done as planned and organized using one and more media for students to be able to achieve certain competence as expected and learning is an effort to and purposed and controlled so other people learn and relative changes appear on other people (Darling-Hammond et al., 2020). That effort is done by someone or team who has skills and competences in design and develop learning sources which are needed.

According to Beatty in Nunan (2003) there are four principles that is need to pay attention to in learning using computer: (1) software program suitability evaluation that is used or source that based on computer for example game or web site, (2) create supporting atmosphere that support the use of computers for example arrange class using computer so interaction can be done properly make 
sure every computer can be accessed easily, (3) pay attention to students' participation in program that use computer and motivate them to do it independently for example define task that need to be done and give responsibility so tasks can be done properly, (4) Encourage the use of computer program as early step to collaborate and interacted with students.

\section{RESEARCH METHOD}

The approach used in this study is mixed method research and Action Research methodology or action research that proactive where it started with training action toward English teacher in SMP Sunan Giri Gresik about how to make and develop English learning material by using computer. The participants belonged to 3 different class groups. Thirty of them were from 8th grade of Amanah class and thirty-two of them from Hidayah class. The other class with thirty participants came from Inayah class. They were trained to make learning material using software then research done in cycles using model John Elliot (1991) with analysis that this model is more detailed and done in 7 steps that is (1) pre research, (2) fact finding and analysis, (3) planning step, (4) action implementation step, (5) failure explanation step, (6) data processing step, (7) data analysis. The kind of data used in this research is quantitative and qualitative. Quantitative data are questionnaire, test (pretest and posttest) and documentation (score). Meanwhile, qualitative is verbal data and narrative data obtained from observation and interview. Quantitative data then integrated so that create meaningful conclusion.

\section{FINDINGS}

To compare the participants' performance, the researcher-made test in Amanah class, Hidayah class and Inayah class. The test result can be seen in table 1 below;

Table 1. Results of Average for Study Pretest

\begin{tabular}{lccc}
\hline \multirow{2}{*}{ Class } & \multirow{2}{*}{ Average } & \multicolumn{2}{c}{ Score } \\
\cline { 3 - 4 } & & Low & High \\
\hline VIII Amanah & 68.0 & 55.1 & 87.2 \\
\hline VIII Hidayah & 47.8 & 33.9 & 62.8 \\
\hline VIII Inayah & 43.5 & 27.2 & 65.0 \\
\hline
\end{tabular}

Based on the analysis in comprehending the English vocabulary of students on early test (pretest) that was given before action implemented found that the highest score students got in VIII Amanah is 87.2 and the lowest is 55.1 
with average score 68.0. While, the highest score in VIII Hidayah is 62.8 and the lowest is 33.9 with average 47.8 . The highest score in VIII Inayah is 65.0 and the lowest is 27.2 with average score is 43.5 . As indicated in the following charts, the low and high of scores in the pre-test suggest the all groups were roughly at the same level concerning their English vocabulary.

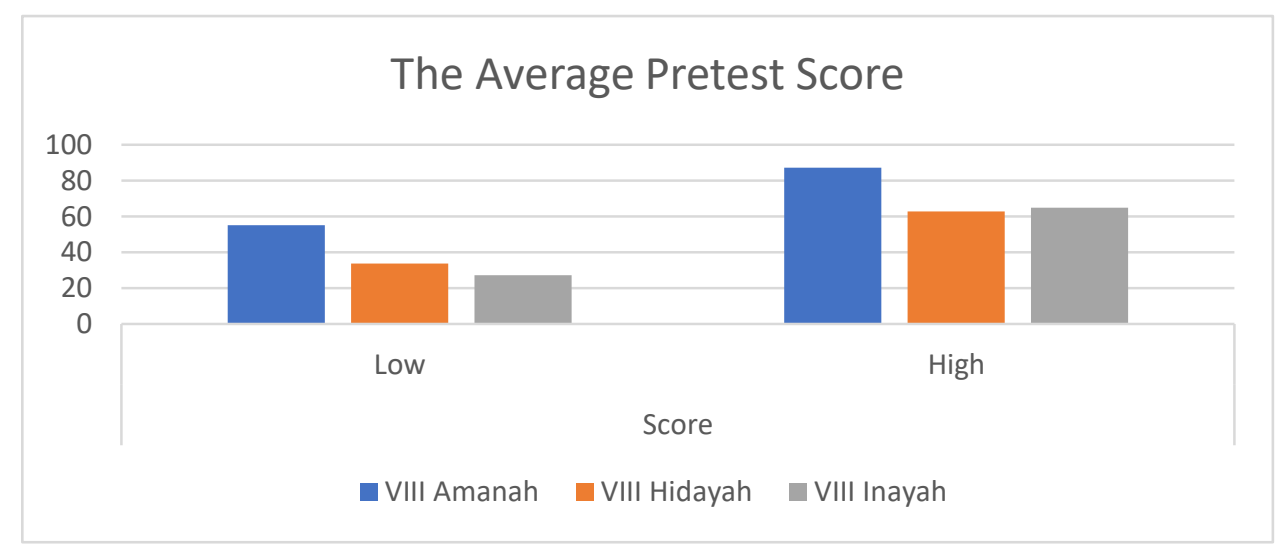

Figure 1. Results of average for study Pretest

\section{Cycle I}

The students of VIII Amanah, VIII Hidayah, and VIII Inayah were given same treatment. These three classes were given test to see the effect and comprehension level of vocabulary. The cycle I acquisition can be seen in table 2 below;

Table 2. The Result in Cycle I

\begin{tabular}{lccc}
\hline \multirow{2}{*}{ Class } & \multirow{2}{*}{ Average } & \multicolumn{2}{c}{ Score } \\
\cline { 3 - 4 } & & Low & High \\
\hline VIII Amanah & 80.6 & 67.5 & 97.0 \\
\hline VIII Hidayah & 58.1 & 50.5 & 70.0 \\
\hline VIII Inayah & 55.8 & 37.5 & 77.5 \\
\hline
\end{tabular}

Table 2, showed that result and average that earned by students in cycle I, there is improvement compare to early test even though not significant, especially in two classes VIII Hidayah and VIII Inayah based on the analysis result in cycle I it is obtained that VIII Amanah students earn the highest score 97 and lowest score 67.5 and average 80.6 students in VIII Hidayah earn highest score 70 and lowest 50.5 the average earned is 58.1 while students in VIII Inayah highest score is 77.5 and lowest score 37.5 and average score 55.8. The result after treatment in cycle 1 showed the improvement in vocabulary comprehension especially VIII Amanah that acquire high scores while students in VIII Hidayah and VIII Inayah had improved but still in low category. Thus the treatment in mastering 
vocabulary still need some fixing. It can be concluded that treatment in cycle I has not yet reached the target and it needs further action on next cycle.

\section{Cycle II}

Based on evaluation result and reflection done in cycle I in cycle II students in class were given treatment English learning with computer assisted conducted in computer lab. During the learning process, each student given chance to interact and did through computer after treatment during 12 meetings all students in three classes then given test to find the improvement and their English vocabulary comprehension level. Based on action implementation in cycle 2 it can be obtained (a) all students in three classes VIII Amanah, VIII Hidayah, VIII Inayah very enthusiastic and active following the learning through computer especially in doing exercises that given through computer, (b) the material and the exercise given by collaborator teacher challenge student that they happy and enthusiastic in doing it, (c) learning material very various and attract student passion. it caused by the new software hot potatoes which is various where students interact directly with the computer, (d) teacher had enough time to monitor and control students in learning process, (e) time to interact among students can be done properly where the exercises were done in pair in group or individually, (f) learning process through computer done by teacher has done properly giving them chance to improve their English vocabulary, (g) teacher had enough time to monitor and helping student in learning because learning portion mostly focus on students skill improvement and student achievement in cycle II can be seen in table 3 .

Table 3. The Result in Cycle 2

\begin{tabular}{lccc}
\hline \multirow{2}{*}{ Class } & \multirow{2}{*}{ Average } & \multicolumn{2}{c}{ Score } \\
\cline { 3 - 4 } & & Low & High \\
\hline VIII Amanah & 94.5 & 55.1 & 87.2 \\
\hline VIII Hidayah & 80.8 & 33.9 & 62.8 \\
\hline VIII Inayah & 80.0 & 27.2 & 65.0 \\
\hline
\end{tabular}

Seeing the result earned by the students as participant in three classes showed that goal achievement or learning target through actions given in cycle II. It showed there was improvement that quite significant where the average score from VIII Amanah increase to 94.5 in VIII Hidayah to 80.8 and VIII Inayah increase to 80.0 so no need further action for cycle III. In cycle II learning process went well where all students seemed enthusiastic active in learning interactively either with teacher or computer. Teacher did not find any difficulty controlling 
and monitoring students in learning especially when they are learning and doing the tasks. Exercise form given by teacher to improve English vocabularies is very interesting and challenging for student's skill to be solved and mastered, the use software in this cycle very suitable to train English vocabulary skill because it gave them chance to the students to explore English vocabularies skill. In this software there are some kind of activities and exercises to improve student's skill such as quiz random words multiple choice and crosswords where all exercise given can be done individually in pair or in group.

Table 4 Posttest Average Score

\begin{tabular}{lccc}
\hline \multirow{2}{*}{ Class } & \multirow{2}{*}{ Average } & \multicolumn{2}{c}{ Score } \\
\cline { 3 - 4 } & & Low & High \\
\hline VIII Amanah & 87.5 & 71.2 & 98.8 \\
\hline VIII Hidayah & 69.6 & 51.7 & 85.0 \\
\hline VIII Inayah & 71.8 & 57.2 & 87.0 \\
\hline
\end{tabular}

Based on analysis of students English vocabulary improvement on posttest given after treatment it is found that the highest score in VIII Amanah is 98.8 and the lowest is 71.2 while average is 87.5 the highest score in VIII Hidayah is 85 and lowest is 51.7 and average score is 69.6 while average score is 71.8 . For clearer result on posttest in three classes can be seen in table 4. It showed that after treatment on two cycles all students as participant in VIII Amanah, VIII Hidayah, VIII Inayah improved in vocabulary comprehension showed by the post test that increased significantly compared to pretest. This showed that the significant improvement proved that students' comprehensions in vocabulary are improved so treatment no longer given and the cycle stopped on cycle two.

Table 5 The Comparison of Pretest - Posttest Average Score

\begin{tabular}{lccc}
\hline Class & Pretest & Posttest & Increase (\%) \\
\hline VIII Amanah & 68.0 & 87.5 & 24.5 \\
\hline VIII Hidayah & 47.8 & 69.6 & 26.8 \\
\hline VIII Inayah & 43.5 & 71.8 & 33.3 \\
\hline
\end{tabular}

From data result calculation showed there is incensement average score in three classes. VIII Amanah class from average score 68,0 on test become 87,5 on posttest where it increases $24,5 \%$ VIII Hidayah average score from 47,8 on pretest become 69,6 on posttest the increasement is 26,8 while class VIII Inayah average score 43.5 on pretest become 71,8 on posttest the increasement is 33.3 learning process through computer conducted during treatment study analyzed 
qualitatively. The data obtained from observation during learning process also interview with collaborator teacher also students and analyzed qualitatively.

\section{Student English Vocabulary Comprehension Improvement}

The result showed that students' English vocabulary comprehension is improved. It is seen through pretest and post test result which given before and after treatment using computer. From the test result given after treatment on cycle I, it showed some improvement in mastering English vocabulary compared to before receiving the treatment, even though the improvement was not significant. It happened because of some factors, such as; a) student attention could not be fully focused because the material given through computer did not explored student's vocabulary and skill, b) students had not given chance to interact directly with computer because the material presented by teacher through computer still classic (Kaplan \& Owings, 2013). The material delivered because some students still passive and did not focus in learning. The result from students after test conducted after cycle I improved but not significantly especially VIII Hidayah and VIII Inayah class. The differences between result of test in cycle I and cycle II, there are showed significant improvement on English vocabulary comprehension compared to previous cycle. So, this researcher is not to continue the next cycle.

\section{English Learning Improvement with Computer Assisted Effectively}

In this research, the effectivity in learning can be seen from test result on cycle I and cycle II. The comparison pretest and posttest, mid-semester result that gotten from students after the cycle 1. Learning result on odd semester gotten from students after cycle 2 finished. Learning effectivity can be seen from observation result during learning process also questionnaire given after post treatment on cycle I and II.

Table 6. The Cycle 1 Score

\begin{tabular}{lcc}
\hline Class & Low Score & High Score \\
\hline VIII Amanah & 67.5 & 98.0 \\
\hline VIII Hidayah & 52.5 & 67.5 \\
\hline VIII Inayah & 37.5 & 75.5 \\
\hline
\end{tabular}


Table 7. The Cycle 2 Score

\begin{tabular}{lcc}
\hline Class & Low Score & High Score \\
\hline VIII Amanah & 72.5 & 100.0 \\
\hline VIII Hidayah & 67.5 & 95.0 \\
\hline VIII Inayah & 65.0 & 97.5 \\
\hline
\end{tabular}

The test result on cycle I showed that student comprehension on learning English vocabulary improved especially students of VIII Amanah with lowest score 67.5 and the highest score 98. Students in VIII Hidayah class only reach 67.5 for the highest score and 52.5 for the lower score, while students in VIII Inayah highest score is 77.5 and lowest score 37.5. Nevertheless, on cycle 2 there is some significant improvement. Students in VIII Amanah reach the highest score 100 and the lowest 72.5. Students in VIII Hidayah with the highest score 95 and lowest 67.5 while the students in VIII Inayah score the highest 97.5 and the lowest 65

Table 8 Pretest Average Score

\begin{tabular}{lccc}
\hline \multirow{2}{*}{ Class } & \multirow{2}{*}{ Average } & \multicolumn{2}{c}{ Score } \\
\cline { 3 - 4 } & & Low & High \\
\hline VIII Amanah & 88.3 & 85.0 & 93,0 \\
\hline VIII Hidayah & 73.1 & 65.0 & 83,0 \\
\hline VIII Inayah & 72.3 & 65.0 & 81,0 \\
\hline
\end{tabular}

Mid-semester results obtained after treatment on cycle 1 showed there is some improvement in learning result where students VIII Amanah class got average score 88.3 with highest score 88 and the lowest 85 students VIII Hidayah got average score 73.1 with the highest score 83 and the lowest is 65 while students in VIII Inayah got average score 72.3 with highest score 81 and the lowest is 65. In conclusion the English learning using computer is quite effective in improving English learning result. 
Table 9 Posttest Average Score (Cycle 2)

\begin{tabular}{lccc}
\hline \multirow{2}{*}{ Class } & \multirow{2}{*}{ Average } & \multicolumn{2}{c}{ Score } \\
\cline { 3 - 4 } & & Low & High \\
\hline VIII Amanah & 90.2 & 72.0 & 98.0 \\
\hline VIII Hidayah & 74.9 & 65.0 & 85.0 \\
\hline VIII Inayah & 73.7 & 69.0 & 83.0 \\
\hline
\end{tabular}

Meanwhile, the semester result obtained after treatment implementation on cycle II showed improvement in learning result where VIII Amanah got average score 90.2 with the highest score is 98 and the lowest score 72. Students in VIII Hidayah got average score 74.9 with the highest score 85 and the lowest is 65 meanwhile students in VIII Inayah class got average score 73.7 and the highest score is 83 and the lowest is 69 . Thus, it can be said that the treatments given has positive effect on students' activeness especially on cycle 2 treatment.

\section{English Learning Efficiency Improvement with Computer Assisted}

Learning efficiency with computer assisted known from interview result from the teacher that was trained using computer in learning also as collaborator teacher in this study. From interview it is found that English learning using computer is quite efficient based on time consideration that available and energy that need to be used. Thus, teachers do not need to give long explanation to students about learning material because collaborator teacher only display the material on computer screen along with pictures and sound so teacher did not have to write on the board or explain about the material or the topic that is about to learn and only provide the learning material that had been input into computer then students could be more active in learning. Computer assisted learning especially using software gave students chance to explore their English skill especially the vocabulary through interacting directly with computer by doing exercises given individually in pair or group.

\section{Attraction Improvement on English Learning with Computer Assisted}

Learning attraction is known from observation and questionnaire results about behavior and student's opinion about using computer in learning process. During the learning from the observation done by the researcher, in two cycles showed learning that is done by computer making the class situation became interesting and made students focus and active in learning. The activeness was not really appearing in cycle 1 or some students that did not pay attention on the learning so that behaved passively but it was no longer seen and it solved in cycle 2. 
Table 10. The Result of Questionnaire

\begin{tabular}{lcl}
\hline Class & Average & $(\%)$ \\
\hline VIII Amanah & 139,5 & 94.7 \\
\hline VIII Hidayah & 139,4 & 94.6 \\
\hline VIII Inayah & 139,2 & 93.8 \\
\hline
\end{tabular}

From questionnaire result that handed to students in three classes after the treatment implementation in two cycles showed that students' positive response as known that they are interested and motivated to join the learning using computer. It is shown from the average students got score above 125 where VIII Amanah class got average score 139,5 which means $94.7 \%$ students agreed and have positive response toward the use of computer in learning. Students in VIII Hidayah got average score $139,4 \%$ or $94,6 \%$ from the students have positive response while students in VIII Inayah got average score 139,2 or 93,8\% participants have positive response in learning using computer that indicated to learning using computer has high attraction which affect in improvement of their English vocabulary.

\section{DISCUSSION}

From the result above, it is found that cycle I treatment did not give proper result, including; (a) students did not show the activeness in learning especially in VIII Hidayah and VIII Inayah, (b) the learning material only showed picture through computers with the software that unable to give students chance to interact directly with the computer, (c) the interaction time were lacking, (d) learning process through computer which done by teacher could not improve their English vocabulary, (f) learning material and exercise given through computer did not let students to do it individually nor in team, and ( $\mathrm{g}$ ) teacher did not monitor students in the process.

From the explanation above it can be concluded that English learning in junior high school can be improved with the help of computer assistance in this matter called Computer-Assisted Language Learning (CALL) mainly to improve English vocabulary. The success of this learning can be seen from three indicators, there are effective, efficiency and attraction (Dlouhá, Barton, Janoušková, \& Dlouhý, 2013).

Meanwhile, in cycle II, there is an improvement in learning result especially English vocabulary. In cycle II, the improvement on students' activeness in class is also seen. It is increased significantly and reached the expected result. Indication on achievement can be seen on: (1) students as participant in three classes VIII Amanah, VIII Hidayah and in VIII Inayah showed 
activeness in learning process, (2) learning material through computer using software gave students to interact directly with computer, (3) Teacher and student interact nicely, (4) the interaction time can be done optimally, (5) learning process through computer done by teacher gave students chance to improve their English vocabulary, (6) learning material and exercise given to students gave them chance to do it individually, in pair and in group, (7) using software teacher can monitor and lead each students in learning. Seeing this result design revision is not needed and do not continued on next cycle.

In the early treatment (cycle 1), the students in three classes looked active in learning compared to before the treatment is given. The use of computer is not a new thing for students because it is taught every week in computer lesson, they did there only to learn about computers part and how to use it to ease works. Students' enthusiasm in learning through computer. The learning material made by the teacher especially material or exercises for students challenge their skill in English vocabulary. Thus, on cycle it was clear that all students were involved actively in learning. Interact with teacher, students and computer in solving and answering the quiz or exercises given by teacher through computer. From the interview with teacher, it is found that they are very excited to teach the students because they have known the use of computer that they have tried caused by inability to use it. Limitation on choosing the material that can be presented through computer and the fact that they did not know the software to use in English learning. They assumed that the use software such as cue cards and software are very effective and suitable used in the learning of vocabulary. This is caused by the software provide material that easy to make by teacher and easy to do by the students.

\section{CONCLUSION}

Learning result improvement also English vocabulary comprehension is not influenced by students' early skill. It can be seen from the learning result and the achievement reached by students in three classes showed significant progress even though they are from three different classes' early skill seen from report score and their grouping in class also if we see from early score.

This study found that; (1). Computer Assisted Learning can improve student's English vocabulary comprehension level. (2). Assisted Computer learning can improve affectivity English learning measured from the learning result score obtained on the given test. (3). Assisted computer learning can improve efficiency English learning. (4). Assisted computer English learning can improve learning attraction for students. It is showed that the theory of CALL provided interaction between teachers and student which helped students develop their thinking skills, made learning and teaching process become more student- 
centered. CALL also increased learners' autonomy and helped them feel more confident and motivate in increasing foreign langauge vocabulary. Therefore, it is suggested for teacher to have creativity in making learning material become more interesting and various. So, students do not feel bored and unmotivated.

\section{REFERENCES}

Ahmadi, M. R. (2018). The Use of Technology in English Language Learning: A Literature Review. International Journal of Research in English Education (IJREE).

Alqahtani, M. (2015). The importance of vocabulary in language learning and how to be taught. International Journal of Teaching and Education. https://doi.org/10.20472/te.2015.3.3.002

Darling-Hammond, L., Flook, L., Cook-Harvey, C., Barron, B., \& Osher, D. (2020). Implications for educational practice of the science of learning and development. Applied Developmental Science, 24(2), 97-140. https://doi.org/10.1080/10888691.2018.1537791

Dick, W., Carey, L., \& Carey, J. O. (2005). The Systematic Design of Instruction. New York: Pearson Education, Inc.

Dlouhá, J., Barton, A., Janoušková, S., \& Dlouhý, J. (2013). Social learning indicators in sustainability-oriented regional learning networks. Journal of Cleaner Production. https://doi.org/10.1016/j.jclepro.2012.07.023

Elliott, J. (1991). Action research for educational change. In Developing teachers and teaching.

Gagne, R. M., \& M, G. R. (1984). The condition of learning. Gagne $R M$. Domains of Learning. Interchange.

Ghavifekr, S., \& Rosdy, W. A. W. (2015). Teaching and learning with technology: Effectiveness of ICT integration in schools. International Journal of Research in Education and Science. https://doi.org/10.21890/ijres.23596

Gilakjani, A. P. (2017). A Review of the Literature on the Integration of Technology into the Learning and Teaching of English Language Skills. International Journal of English Linguistics, 7(5), 95(2). https://doi.org/10.5539/ijel.v7n5p95

Hadi, F. N., Raja, P., \& Flora, F. (2017). Language Learning Strategies Used by Thai Students in Learning English and Indonesian. UNILA Journal of English Teaching.

Hashemi, A. (2016). The Impact of Information and Communication Technology (ICT) on Teaching English to College Students. EFL JOURNAL, 1(3). https://doi.org/10.21462/eflj.v1i3.20

Kaplan, L. S., \& Owings, W. A. (2013). Culture Re-Boot: Reinvigorating school culture to improve student outcomes. In Culture Re-Boot: Reinvigorating School Culture to Improve Student Outcomes. https://doi.org/10.4135/9781452277974 
Koran, S. (2015). The Role of Teachers in Developing Learners' Speaking Skill. Conference: 6th International Visible Conference on Educational Studies and Applied Linguistics - 2015, At Erbil,Iraq. Retrieved from https://www.researchgate.net/publication/322112785_The_Role_of_Teach ers_in_Developing_Learners'_Speaking_Skill/link/5a459b71a6fdcce1971 a6146/download

Leu, E. (2005). The Role of Teachers, Schools, and Communities in Quality Education: A Review of the Literature. In Education.

Md Ruhul, A. (2019). The Role of Educational Technology in the ESL Classroom. Global Journal of Archaeology and Anthropology. https://doi.org/10.19080/GJAA.2019.11.555801

Nation, I. S. P. (1974). Language Teaching Techniques. Yogyakarta: Unpublished Materials. FKSS.

Noor-Ul-Amin, S. (2013). An Effective use of ICT for Education and Learning by Drawing on Worldwide Knowledge, Research, and Experience : ICT as a Change Agent for Education. Department of Education University of Kashmir.

Nunan, D., Bailey, K., Anderson, N., \& Sokollik, M. (2003). practical English language teaching. In Language.

Shabaneh, Y., \& Farrah, M. (2019). The Effect of Games on Vocabulary Retention. Indonesian Journal of Learning and Instruction, 2(1), 79-90.

Smaldino, S. E., Lowther, D. L., \& Russel, J. D. (2007). Instructional Technology and Media for Learning. New Jersey: Pearson Education, Inc.

Wahid, A., Hajriana, \& Andri, C. (2009). Strategi Belajar dengan Aneka Sumber. 